\title{
Baso-eskola proiektu pilotuko haurren ebaluazio hezigarria burutzeko adierazleen definizioa
}

\author{
Definition of an educative assesment model for children \\ in a forest school pilot project \\ Josu Sanz Alonso*1, Maialen Sistiaga Poveda ${ }^{2}$, Pello Urkidi Elorrieta ${ }^{1}$, \\ Irati Andoño Erdozain ${ }^{2}$, Kakun Orbegozo Rezola ${ }^{2}$ \\ 1 Hezkuntza, Filosofia eta Antropologia Fakultatea (UPV/EHU) \\ 2 Kutxa Ekogunea
}

LABURPENA: 2017ko urritik Haur Hezkuntzako hiru ikasketa zentroek (Hernaniko Langile Ikastolak, Donostiako Amara Berri eskolak eta Alkizako eskola txikiak) Kutxa Ekoguneko baso-eskola proiektua pilotatzen dute. Etorkizunean baso-eskola proiektua beste ikasketa zentroetara zabaldu nahi dela-eta, Euskal Herriko Unibertsitateak (UPV/EHU) proiektu honetako arlo desberdinak sistematizatu eta ebaluatzea du helburu. Besteak beste, haurren garapen kognitibo zein afektiboa, ingurune naturalaren egokitasuna eta proiektuan parte hartuko duten tutoreen jarraipena. Honen bidez, arlo hauen inguruko ezagutza zientifikoa eta proiektu pilotuaren zilegitasuna lortzea espero da baina ez hori bakarrik, baita unibertsitate mailako ikasketak aberasteko aukera ere, gure ikaslegoaren parte hartze potentzialaren bidez.

HITZ GAKOAK: Haur Hezkuntza, ingurune naturala, ebaluazioa, baso-eskola.

\begin{abstract}
Three early childhood schools (Langile Ikastola from Hernani, Amara Berri from Donostia and the school from Alkiza) will develop their 2017-2018 school year as a pilot project in basoeskola from Ekogunea (Fundación Kutxa). The main objective of this work is to present is to present the evaluation model developed for measuring the potential benefits of the participant children in their continous contact with nature. Among the developed or adapted indicators, it can be mentioned the measurement of the cognitive and affective development of the participant children, the suitability of the environment as an educative facility, free play or their environmental attitudes. As a result nine indicators have been developed, which will be validated in this year's experience, but are easily applicable by other educative centers. Also, this proposal aims to generate scientific knowledge of the benefits of children's nature education, an area with scarce development.
\end{abstract}

KEYWORDS: early childhood education, natural environment, evaluation, forest school .

\footnotetext{
* Harremanetan jartzeko / Corresponding author: Josu Sanz Alonso. UPV/EHU. Matematikaren eta Zientzia EsperimentaIen Didaktika. Hezkuntza, Filosofia eta Antropologia Fakultatea. Magisteritza Eraikina (HEFA II). Oñati Plaza 3. 20018 Donostia/San Sebastian - josu.sanz@ehu.eus - http://orcid.org/0000-0002-1211-1598

Nola aipatu / How to cite: Sanz Alonso, Josu; Sistiaga Poveda, Maialen; Urkidi Elorrieta, Pello; Andoño Erdozain, Irati; Orbegozo Rezola, Kakun. (2018). «Baso-eskola proiektu pilotuko haurren eba luazio hezigarria burutzeko adierazleen definizioa»; Tantak, 30(2), 63-78. (https://doi.org/10.1387/ tantak.19322)

Jasotze-data: 2018/03/08; Onartze-data: 2018/04/30.
}

ISSN 0214-9753 - elSSN 2444-3581 / (C) 2018 UPV/EHU

(c) ${ }_{\mathrm{By}}$ Obra hau Creative Commons Atribución 4.0 Internacional-en 


\section{SARRERA}

EAEko 237/2015 Dekretuak adierazten duenaren arabera, oinarrizko konpetentziak garatuz haur guztien garapen osoa eta orekatua lortzen laguntzea da Haur Hezkuntzaren xedea. Arau-esparru horrek berak dioenez Haur Hezkuntzan haurren bizipenak dira hezkuntza-planteamenduaren funtsa eta ingurune fisikoarekin, ingurune naturalarekin eta gizartearekin dituen hartuemanen harian eraikitzen du haurrak nortasun pertsonala. Dekretuak ingurumenaren garrantzia aitortzen du, «haurraren eskolak ingurunera zabaldu eta arreta jarri behar diola haurrek eskolatik kanpo bizi dituzten esperientzien ekarpenari», «haurren jakin-min eta interes handia pizten dutelako ingurune naturalak eta haren baitako izaki eta elementuek» aipatuz. Ingurune fisiko horren azterketaren, behaketaren, esplorazioaren, ikerketaren eta jolasaren bidez ezartzen baititu haurrak elementuen arteko erlazioak.

Dena dela, gure ikastetxeen errealitatea bestelakoa da. Izan ere, ikasketa zentro gehienak ingurune naturaletik hurbil badaude ere, naturarekiko kontaktua mugatua eta ez-jarraia da, ordutegi gehiena barne-espazioetan gertatzen da eta oro har ez da inguruko bioaniztasunari buruzko aipamenik egiten. Horrez gain, irakasle zein guraso ugarik arrisku potentzialak ikusten dituzte ikasgelatik kanpo, eta naturaren inguruko ezagutza baxua izan ohi da. Hala ere, Haur Hezkuntza bera testuinguru heterogeneo, anitza eta irekia da eta hain zuzen horren baitan kokatzen da Kutxa Ekoguneko basoeskola proiektua Amara Berri (Donostia), Langile ikastola (Hernani) eta Alkizako eskolen partaidetzarekin 2017-2018 ikasturtean.

Proiektu pedagogiko berritzailea da, hezkuntza eta natura bateratzea oinarri duena, EAEko hezkuntza sisteman integratua eta Eusko Jaurlaritzak babestutakoa. Horrela, 2016ko apirilean sortu zen Batzorde Teknikoan Berritzeguneak, Ingurugela-CEIDAk eta Ikastolen Federazioa edo UPV/ EHUk parte hartzen dute, besteak beste.

Proiektu pilotuaren ezarpena apustu sendoa izan da Kutxa Ekogunearen aldetik eta zenbait eraldaketa eragin du, besteak beste: Zabalegi (Hernani eta Donostiako udalerrien artean kokatuta dauden $4 \mathrm{Ha}$ ) lursaileko eremu naturalaren egokitzapena segurtasun bermeak betetzeko, Langile, Amara Berri eta Alkizako tutoreak ingurune naturalean daudenean laguntzeko pertsonal adituaren kontratazioa, egurrezko bi txabolen eraikuntza (1. irudia), jangela zerbitzuaren kontratazioa, baso-eskola formazio espezifikoaren garapena Prest Gara ekimenaren bidez zein parte hartu nahi duten ikasketa zentroentzako; edo basorako garraio zerbitzua Donostiako eta Hernaniko udalekin lankidetzan.

EHUren partaidetzari dagokionez, eta Kutxa Ekogunearen helburua etorkizunean metodologia hau beste ikastetxe batzuetara zabaltzea delaeta, beharrezkoa ikusten zen proiektu pilotuan haurren parte hartzea gertatzen zen momentutik (2017ko urria) ebaluazio bat garatzea. Horrela, esperientzia honetako arlo desberdinak aztertu nahi dira, besteak beste, haurren 
trebetasun kognitiboak edo fisikoak sustatzeko egokitasuna, ingurumenarekiko jarrera positiboak, baina baita ingurumenaren egokitasuna ere, irisgarritasun eta segurtasunari dagokienez.

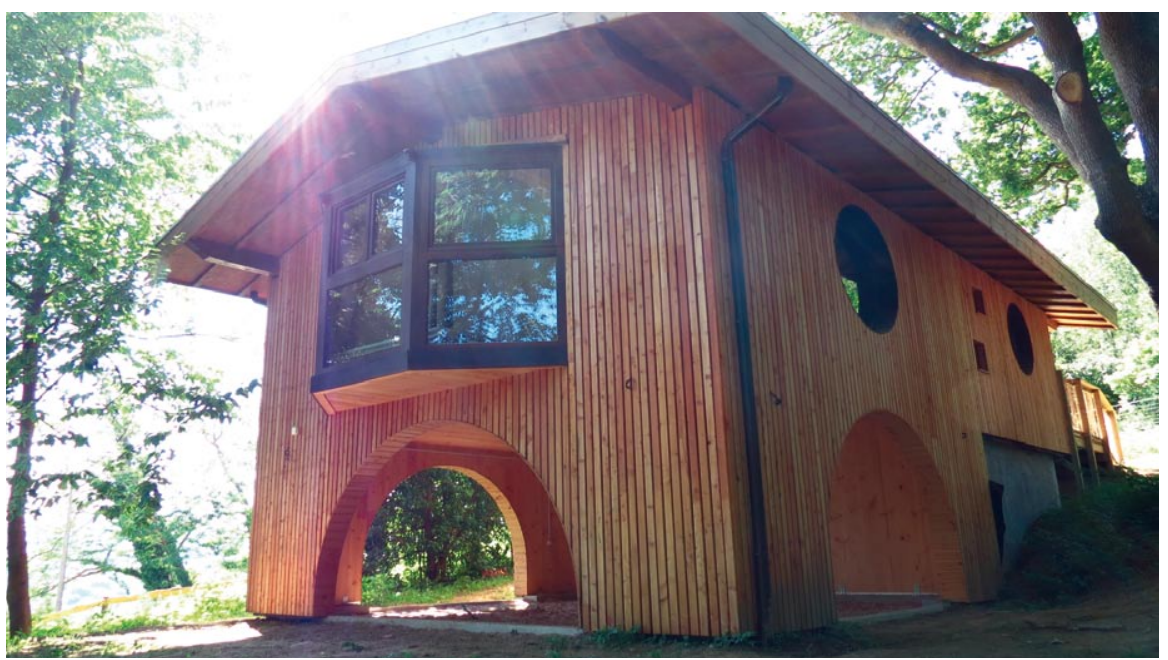

1. irudia

Kutxa Ekoguneko baso-eskolako egurrezko etxola

\section{BASO-ESKOLAK ETA HAIEN ONURA POTENTZIALAK}

Baso-eskola kontzeptua ez da berria, Suedian eta Danimarkan, esate baterako, 50eko hamarkadatik garatzen dute metodologia hori, 60eko hamarkadan Alemanian hedatu zen - mota horretako 450 zentro zeuden Alemanian 2005ean - , eta geroago herrialde anglosaxoietara zabaldu (O’Brien, 2009). Hezkuntza-ikuspegi berri horren bidez natura bihurtzen da baliabide pedagogiko nagusia, baina horrez gain haurren jolaserako eta aurkikuntzarako berezko gaitasunak sustatzeko ingurune ezin hobea bilakatzen da, Pestalozzi-k (1816-1819, 2006), Montessori-k (1909/2016) edo Pliker-Loczy-k (1969) inspiratutako metodologietan oinarrituz (Kuh, 2014). Dena dela, oraindik mota horretako ikastetxe gutxi daude Espainiar Estatuan, Cercedako Bosquescuela, Madrilen; edo EAEn Arabako PlistiPlasta eskola eta Donostiako Ulia muinoko Bihotz Inguru eskolak, batzuk aipatzearren.

Arestian aipatu bezala, Kutxa Ekoguneko baso-eskola proiektu pilotuaren helburua baso-eskola bat sortzetik harago doa. Ezagutza eta iker- 
keta garatzeko esparru gisa ulertu behar da, etorkizunean metodologia eta filosofia hori beste eskoletara hedatzeko helburu duena. Hori dela-eta, proiektu pilotua ebaluatzeko asmoaren baitan, esperientzia erreal batean oinarritutako ezagutza zientifikoa eskuratzeko aukera sartzen da, bi arlo nagusitan. Alde batetik, haurrak ingurune naturalarekiko harreman jarraia edukitzeagatik egon litezkeen onura kognitibo-afektibo potentzialak aztertzen dira; baina bestetik, basoak marko pedagogiko gisa egin dezakeen ekarpena ulertzen da. Dena dela, bi arlo horietan aurki daitekeen literatura zientifikoa urria da, maiz Haur Hezkuntzako etapari ez baitzaio merezi duen garrantzirik ematen, nahiz eta ezaguna den fase horretan duela bereziki haurraren adimenak garapenik eta plastikotasunik handiena (O'Neill eta Polman, 2004). Natur inguruneariko kontaktuari dagokionez, literaturak balio afektiboak eta jarrerak jasotzen ditu batik bat, baina ez da hainbeste aztertzen haurraren garapen kognitiboa.

Esan daiteke haurren garapen kognitiboaren inguruko interesa nahiko kontu berria dela. 70eko hamarkadatik aurrera hasi ziren haurren gaineko lehen behaketa enpirikoak eta orduan ohartu ziren haurrak gai direla fenomeno naturalei buruzko pentsamendu propioak garatzeko. Piageten gerraosteko psikologia ebolutiboari buruzko ekarpen esanguratsuek frogatu zutenez, haurraren heltze prozesuak ikaskuntzarekin zerikusi handia du, garapenarekin estuki lotuta dagoela esan daiteke. Piagetek defendatzen du eboluzio-fase desberdinetan dauden haurrak gai direla eskema kontzeptualak eratzeko ingurunearekiko elkarrekintzan. Piagetek definitutako lau faseetatik bi Haur Hezkuntzako aldiari dagozkio: aldi sensorimotorea eta etapa aurre-operazionala (Piaget, 1964). Hain zuzen bi aldi horiek dira ezinbestekoak kausa-ondorioak ulertzeko, hipotesiak sortzeko edo ingurune erreala interpretatzeko burutapen mental sinpleak eraikitzeko. Hori guztia esperimentazio, behaketa eta antzezlanen bidez, «errealitatearekin elkarrizketan» egongo balira bezala (Pedreira, 2006). Oinarri horretatik abiatuta, 80ko hamarkadan zientziaren didaktika sendotu zen Ausubel, Novak eta Hanesian-en (1978) psikologia kognitiboko ekarpenei esker, baita Driverren (1983) ikasketa esanguratsu eta ez-errepikakor eta aurre-ideien garrantzia ikusita ere. Ondoren, Vigotskyk (1979) konstruktibismo sozialari buruzko teoria argitaratu zuen, argudiatuz ikasketa prozesua soziala dela, hau da, norberaren eta inguruaren arteko erlazioetan oinarritzen dela. Azken hamarkadetan, Haur Hezkuntzari buruzko ikerketa bi arlo desberdin baina osagarritan bereizten da, era berean bi mugarri sendo dituztenak. Alde batetik, Gardnerrek (1983) definitutako «inteligentzia anitzak», haurrek modu indibidualean sustatu behar diren gaitasun desberdinak (musikala, artistikoa, hitzezkoa...) dituztela aldarrikatzen duena. Gardnerrek goraipatzen du garapen indibiduala ahalbidetzen duen inguru global baten beharra, ikasgela hezigarri eta hezitzaile batetik kanpo. Eredu honek inspiratutako hezkuntza-metodologiak ugariak dira, Spectrum eredutik hasi (Garcia Ruiz, 2013) eta «konfiantzaren pedagogian» oinarritutako propo- 
samenetaraino (Jackson, 2001), ingurunera irekita dauden hormarik gabeko ikastetxeak aldarrikatzen dituena eta Euskal Herriko ikastetxeetan zabaltzen ari dena. Beste mugarria, zientziaren didaktikan oinarritutakoa, eredu mentalen (inquiry based modeling) garapen eta esperimentazioan zentratutako lanak dira, gainera frogatu da hauek haurtzaroan garatzea posiblea dela (Martin, Raynice, eta Schmidt, 2005; Siry, 2014). Eredu horietan guztietan inguru aberats, anitz, estimulatzaile eta aldakor baten beharra dago, ikasgelatik kanpo ematen diren une puntualetatik harago doana, haurrak garapen kognitibo esanguratsu eta natural baterantz bideratzen dituena. Izan ere, pertsonen eboluzio prozesua norbanakoaren eta inguruaren artean ezartzen den eraikuntza prozesu dinamikoa da. Ondorioz, Kamiik eta deVriesek (1989) adierazten duten moduan gertakarien behaketa zein deskribapenetik harago doan jarduera fisiko eta mentala garatu dadin ingurune aberatsa behar da, haurrek elementuekin jardun eta elkarreragin dezaten eta ingurune naturalean gertatzen direnetatik bereizten dituzten transformazioak eragin ditzaten.

Kamiik eta Frabbonik (1980) bat egiten dute, ikastetxe ireki eta esperimental baten sorrerari dagokionez, batez ere Haur Hezkuntzako etapan garrantzia duelako. Beti kontuan izanda hiriguneak ere haurren ingurua badirela, nahiz eta gabeziarik handienak ingurune naturalean ikusten diren.

Haur Hezkuntzako etapan, beste etapetan baino gutxiago suertatzen diren arren, ohikoak dira ere eskolaz kanpoko irteerak. Dena dela Waitek (2015) adierazten duen moduan, gehienetan irteera horiek ikastetxetik hurbil dagoen parke batera egiten dira eta beste ume batzuekiko hurbilketa bat baino ez da egoten. Are gehiago, garai batean auzoetan izaten zen jolas librea eta ingurunearen esplorazio maila ere murriztu egin dira eta haurrei auzoa modu librean ezagutzeko aukera mugatu zaie (Waller, Sandseter, Wyver, Ärlemalm-Hagséry eta Maynard, 2010).

EAEko egoerari dagokionez, ikastetxe ugarik eta bereziki Eskola Agenda 21 programak bultzatuta eskola-baratza jarri dute martxan eta hondakinen gaia, bioaniztasuna edo elikadura arduratsua bezalako gaien lanketa egiten dute. Horrez gain, geroz eta gehiago dira Euskal Herrian baserri-eskoletara, ingurumen-hezkuntzako zentroetara edo inguruko parke naturaletara irteerak egiten dituzten Haur Hezkuntzako ikastetxeak ere. Hala ere, Ghafourik (2014) defendatzen duen moduan haurren eta naturaren arteko kontaktuak jarraikortasuna izan behar du, eremu natural puruenetatik hasi eta parke urbanizatuetaraino. Ikertzaile honen arabera, baserrietara edo antzeko lekuetara egiten diren irteera puntualek ez diete motibazio gehigarririk eragiten haurrei eta haurrek ez dute loturarik egiten aurretik ikasitakoarekin. Beraz, naturarekin harreman ez-zuzen honek ez die bermatzen errealitatearen ezagutzan sakontzea, ziklo naturalak ezagutzea edo naturaren ereduei jarraitzea, eta ondorioz ez dute haien inguruari buruzko ezagutza errealik eta esanguratsurik sortzen. Aldiz, ekosistema batekiko kontaktua jarraia bada, ikasketa benetan esanguratsua bilakatzen da, 
prozesu konplexu eta ez-linealak barneratzen dituelako eta haurrak pitinka-pitinka hurbiltzen direlako errealitatearen interpretaziora. Testuinguru hauetan kokatzen da hain zuzen Falkek eta Dierkingek $(2002,9)$ definitutako ikasketa prozesua, hautaketa librea, «autogidatua, boluntarioa eta norberaren interes eta beharretatik gidatutakoa» nabarmentzen duena eta aukeratzeko askatasuna ematen duena: zer, noiz, non eta nola ikasi nahi den. Hala ere, ikasketarako ingurune seguru bat izan behar da, inolaz ere ez ingurune basati bat. Horregatik, nabarmendu behar da Haur Hezkuntzako tutoreek betetzen duten asistentzia-lana, haurrek maiz ekintza ugarietan laguntza behar dutelako oraindik eta arreta berezia jarri behar delako haurren segurtasun emozionala bermatzeko. Essak (1981) dio kanpo-espazioen diseinuak adin honetan ematen diren hiru jolas motak izan behar dituela kontuan: jolas fisikoa, soziala eta kognitiboa. Gainera, espazio horrek esperientzia anitzak bideratu behar ditu eta haurrei ingurunearekin eragiteko nolabaiteko erraztasuna eman. Clarkek (2007) dio, jolaserako eta ingurunearen ezagutzarako kanpo-espazioak eskaintzen direnean, besteak beste ezaugarri hauek izan behar dituztela: erabilera pribaturako espazioak, espazio pertsonalak, espazio sozialak eta sormenerako espazioak. Hau da, kontuan izan behar da ikasketa-prozesua ez datorrela beti inguruneko elkarrekintzaren eskutik, baizik ingurunearen ezagutzaren eta beste haurrekin izan daitekeen elkarrekintzaren bidez.

McClintic-en arabera (2015), naturarekiko kontaktuak onura nabariak ditu haurrengan. Horien artean inteligentzia naturalista nabarmentzen da (Gardner, 1999), sormena bultzatzen da gorputz osoari esperientzia multisentsorialak eskaintzen zaizkiolako, esperimentaziorako aukerak sortzen dira, objektu eta gertakizunen artean loturak egitea ahalbidetzen da (Fjørtoft, 2004) eta haurren arteko zein helduekiko harremanak hobetzen dira (Wilson, 2008). Maila kognitiboan, kanpo-espazioetan gertatzen den ikasketa-prozesua behaketarekin, ikerketarekin eta hipotesien sorrerarekin lotuta dago (Thomas eta Harding, 2011). Emozionalki, haurrak animalietatik eta ziklo naturaletik gertuago sentitzen dira, aire zabalean egonda sentitzen duten askatasunak animatzen ditu modu librean sentimenduak adieraztera (Magraw, 2011) eta azkenik, arrisku neurtuak hartzeko eta euren jarrerak autogestionatzeko joera handiagoa izaten dute (Thomas eta Harding, 2011). Dena dela, horrek guztiak talka egiten du maiz ikuspuntu alboratu batekin, irakasle eta familia batzuen beldurrekin eta aurreiritziekin. Irakasleek orokorrean ingurune irekian jolasak duen garrantzia onartzen badute ere, eta haurrek ikasketa prozesua emankorra izan dadin esperimentatu eta askatasun sentsazioa izan behar dutela ikusten bada ere, zenbait ikerketatan kontraesan handia ikusten da, tutore askok oraindik ikasgela ikusten baitute benetako ikasketa gune bezala (Maynard, 2012). Bestalde, tutore askok antolakuntzari edo segurtasunari dagokionez zailtasun praktikoak ikusten dituzte eta alderdi metodologikoarekiko mugatuta sentitzen dira - hau da, kanpo-espazioak eguraldi onarekin baino ez dituzte era- 
bilgarri ikusten - , eta, gainera, ingurune naturalarekiko ezezagutza aitortzen dute. Beraz, ingurune naturalen erabilera handitzeko ez litzateke irakasleen motibazioa indartu behar, baizik eta muga hauek murrizten saiatu (Enrst, 2014). Norvegia, Suedia edo Danimarka bezalako herrialde eskandinaviarrak hartu beharko genituzke eredutzat, bertan haurrekin batera esploratu eta berrikusten baitira arrisku potentzialak, zuzenean helduek aginduta hauek debekatu beharrean. Hau da, irakasleok ulertu beharko genuke haurrak erabat gai direla arriskuak ulertzeko eta helduok ez ditugula zertan mugatu (Guldberg, 2009). Hain zuzen herrialde hauetan hasi ziren 50eko hamarkadan baso-eskola ereduko ikastetxeak, ez hainbeste berritzaileak izan zirelako baizik haurrei neurri berean ardurak eta askatasuna ematen zitzaizkielako.

\subsection{Baso-eskoletako ebaluazioa}

Ez da oso ugaria baso-eskoletan egindako ebaluazioei buruzko literatura; ondorioz, aukera bat zabaltzen zaigu Kutxa Ekoguneak hasitako proiektu pilotu honetan. Aurkitutako ia erreferentzia guztiek eredu honen alderdi positiboak goraipatzen dituzte, adibidez, O’Brienek (2009) Galesen eta Ingalaterran egindako baso-eskolei buruzko analisi batean, aurrerapauso handiak ikusi dira haurren konfiantzari, motibazioari eta garapen fisikoari dagokienez. Ikerketa honetan azpimarratzekoa da autoreak zenbait adierazleren eboluzioa ikusten duela epe labur-ertain-luzean, ikasturte bateko 8 hilabeteetan zehar. Erresuma Batuan kokatzen den beste lan batean, Ridgers, Knowles eta Sayers (2012) analisi kualitatibo batean oinarritzen dira - proiektuan parte hartzen duten haurrei egindako elkarrizketen bidez - eta animaliei zein ziklo naturalei buruzko ezagutza handitzen dela ondorioztatzen dute. Lehen aipatu den moduan baso-eskolen bideragarritasuna haurrentzako espazio seguruen eta haurren eta ingurunearen arteko interakzioa bermatzen duten guneen menpe dago. Zentzu honetan MacKinderren (2015) ikerketa interesgarria da, Leuven Involvement and Participation Scale izeneko ebaluazio-tresnaren balioa azpimarratzen duelako eta haur-ingurune interakzioa, heldu(tutore)-haur interakzioarekin zuzenki lotuta dagoela diolako. Autoreak dioen moduan, emaitza hauetan igarri egiten da baso-eskoletan tutoreen murgiltzea bermatuta egon dadin aurrez formazioa egitea ezinbestekoa dela, eta tutoreei jarraipen eta autoebaluazio erremintak eskaini behar zaizkiela. Ildo beretik jarraituta, Harrisek (2015) baso-eskoletako tutoreen ikuspuntua aztertzen du. Interesgarria da profesional hauek elkarrizketa gida-lerro batzuk jarraituta, bere burua «bidelagun» moduan definitzen dutela, irakasle moduan baino gehiago. Honen arrazoia izan daiteke tutoreek ikusten dutela baso-eskolan haurren ikasketa garapen sozial modura gertatzen dela, hau da, talde-lanaren bidez, besteekin harreman sendoak sortzearen bidez, auto-ikasketaren bidez eta auto- 
kontrolaren bidez, baina baita haurrek hartzen dituzten ardurei esker ere. Eta prozesu honetan irakaslearen lana bidelagunarena da gehiago ezagutza kontzeptualen igorlearena baino. Azkenik, Waiteren (2015) lana aipatuko genuke, Erresuma Batuko eta Danimarkako baso-eskolen eboluzioa alderatzen baititu. Bi eredu hauetako filosofia antzekoa bada ere, eskola britaniarretan curriculum estatalarekiko lerratzea handiagoa da eta hein batean galdu egiten dute eskola eskandinavoetako interesgune berriak esperimentatzeko askatasun pedagogikoa, zeinetan tutoreak artea, teknologia berriak edo konfiantzaren pedagogia, besteak beste, naturan txertatzeko askatasun handiagoa duten.
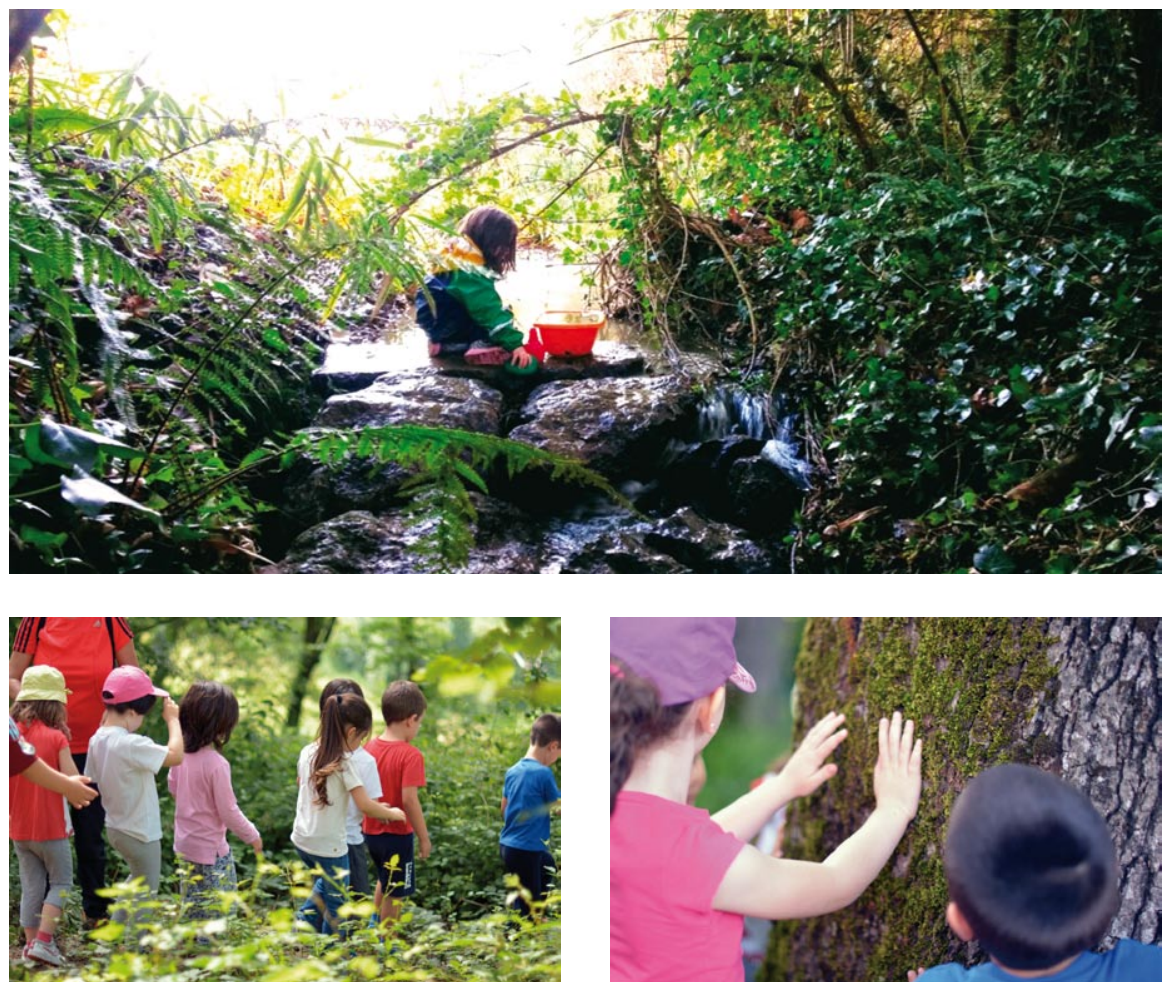

2. irudia

Baso-eskolan gertatzen diren ohiko momentuak

(goitik behera eta ezkerretik eskumara): neskatxa baten jolas librea errekan, eguneroko ibilaldia basora, naturarekin harremana sustatzea (argazkiak: Amara Berri)

Kutxa Ekoguneko baso-eskola proiektu pilotuak oro har aipatutako eredu hauen filosofia partekatzen du baina bere ezaugarri propioak ditu. 
Bereziki, arlo metodologikoei dagokienez, parte hartzen duten hiru ikastetxeek (Hernani eta Donostiako hiriguneetakoak bi, eta Alkizakoa hirugarrena) euren ohiko eredua eta baso-eskola eredua txandakatuko dituztelako, basora ateraz hiru asteko zikloetan: Ekoguneko basora Hernani eta Donostiako kasuetan, edo ostiralero herriko baso batera Alkizakoen kasuan. Honela, ikastetxe bakoitzeko lerro edo ikasgela guztien partaidetza ahalbidetzen da (2. irudia). Beste berezitasun bat litzake ikasleak orain arte hezkuntza-eredu estandar batean murgilduta egon direla, edo beste hitzetan esanda, ez dutela parte hartu naturarekin kontaktu jarraia duten baso-eskola bezalako esperientzia batean. 2017-2018 ikasturtean zehar garatu den pilotaje honetako eszenatoki desberdinek eta Kutxa Ekoguneak etorkizunean esperientzia hau beste testuinguru eta ikastetxeetara zabaltzeko duen bokazioak proiektuaren ebaluazioa ezinbesteko bihurtzen dute.

\section{EBALUATU BEHAR DIREN ALDERDIEN DEFINIZIOA}

Lan honen helburu nagusia Kutxa Ekogunean burutu den baso-eskola proiektu pilotua ebaluatzeko sistema bat garatzea izan da, parte hartuko duten eskolen ohiko ebaluazioen osagarria izango dena, eta naturan kontaktu jarraiaren onurak neurtzeko gai izango dena. Helburu honekin batera, naturan heztearen onuren inguruko ezagutza zientifikoari ekarpena izan nahi dugu. Orain arte, oso gutxi garatuta dagoen ikerketa-arloa da hau, Haur Hezkuntzako etapan behintzat. Hartara, nahiz eta ebaluazio-eredu hau proiektu pilotu honetarako garatua izan den, beste eskola batzuentzako erabilgarria izan dadin bilatu da.

Adierazleak definitzeko, arestian aipatutako ikerketa batzuk (O'Brien, 2009; Ridgers, Knowles eta Sayers, 2012; Harris, 2015, MacKinder, 2015; Waite, 2015) hartu dira oinarritzat eta funtsezko onurak zehaztu dira ikasketari zein haurren garapen pertsonalari dagokienez natur ingurunearekiko kontaktu jarraia dela-eta. Aintzakotzat hartu dira baso-eskola eredu pedagogikoaren (espero izandako) emaitza positiboak, baina Kutxa Ekoguneko ereduak dituen berezitasunak kontuan izanda, baita euskal hezkuntza-sistemako eredu sozial eta arauemailea.

Hori dela-eta, ebaluazioko alderdien definizioari dagokionez asko izan dira sortu zaizkigun zalantzak:

- Zergatik da garrantzitsua honelako metodologia pedagogikoak ebaluatzea? Aintzakotzat hartu behar al dira gaur egungo hezkuntzaeredu markoak (237/2015 Dekretua) ezartzen dituen orientabideak ala exnovo ebaluazio bat sortu behar da?

- Zein alderdi (kognitibo, prozedurakoak, fisikoak) ebaluatu behar dira? Horietakoren bat lehenetsi behar da?

- Zeintzuk dira ebaluazioaren helburuak? Ingurua bera, haurrak, tutoreak, familiak? 
- Zein ebaluazio mota (kualitatibo edo kuantitatiboa) doitzen zaio hobekien eredu honi?

- Eta aurrekoarekin lotuta, ebaluazioak jarraia eta formatiboa izan beharko luke ala parte hartzen duten agenteekin harremanik ez duen ikerketa bat?

- Beste modu batera esanda, ebaluazio partehartzailea izango da?

Horretarako, proiektu-pilotuan parte hartuko zuten haurrak ebaluatzeko (2017-2018 ikasturtea) erraminta batzuk garatzea erabaki zen, ebaluazio globala, jarraia eta hezigarria bermatuta gera zedin; eta euskal hezkuntza-sistemako ebaluazio-estandarrekin bat etor zedin (237/2015 Dekretua). Ebaluazioak anitza behar zuen izan, kualitatiboa eta kuantitatiboa konbinatu, eta haurrak prozesuaren parte-hartzaile bihurtzen zituena. Era berean, baso-eskolan aurreikusten ziren hobekuntzak azpimarratu behar zituen, hala nola jarrerazko alderdiak (konpromisoa, motibazioa, garapen pertsonal eta soziala, jolasarekiko eta ingurunearekiko jarrera), alderdi metodologiko eta operazionalak (gaitasun psikomotoreak, pentsamendu kritikoa eta sormena) eta alderdi kognitiboak (hizkuntza, matematikak edo zientzia bezalako konpetentzia espezifikoak).

Horrez gain, parte hartzen duten helduen ebaluazioa egitea ere erabaki zen, kasu honetan tutoreena, alderdi desberdinak aztertuz: irakasle moduan betetzen duten papera, irakasle-ikasle interakzioak, edo behar propioak (materialak, antolakuntza edo ezagutza), eta mugak.

Ebaluazio honek baso-eskola proiektu pilotuan gertatzen diren ikasketa garrantzitsuenak identifikatu eta kuantifikatzen lagunduko digu, baita baldintzatzen dituen faktoreak ezagutzen ere. Horrela, ebaluazio honekin proiektu pilotua emango den ikasturte honen amaieran, hezkuntza- eta kanpo-faktoreak bereizteko gai izango garelakoan gaude:

- Hezkuntza-faktoreak: tutoreen papera, erabilitako hezkuntza-metodologiak (transmisorea, esperimentala, baliabide desberdinen erabilera), baso-eskolan integratutako proposamen kontzeptual anitzak, besteak beste.

- Zeharkako kanpo-faktoreak: espazioen konfigurazioa, irisgarritasuna, materialen egokitasuna, ziklo naturalekin bat egitea, besteak beste.

Faktore hezigarrien ebaluazioaren bidez baso-eskolak eskola tradizional batekin alderatuta dituen berezko ezaugarriak identifika daitezke, eta, kanpo-faktoreen ebaluazioaren bidez, ingurune fisiko eta natural modura baso-eskolak izan dezakeen egokitasuna baloratuko da.

Azkenik, ikerketa honen helburuetako bat ere bada baso-eskolako puntu-ahulak azaleratzea, eskola tradizional batekin alderatuta. Horretarako, eskola edo kontrol talde bat hartuko da. antzeko metodologia duena, eta proiektu pilotuan ikertuko diren alderdi berdinak ebaluatuko dira. Es- 
kola kontrol hauetan, ebaluazioa ikasturte hasieran eta amaieran egingo da soilik.

\section{BASO ESKOLA PROIEKTU PILOTOAREN ADIERAZLEAK}

Aipatu den bezala, naturan heztearen onurak aztertzen dituzten ebaluazio-irizpideak definitzen dituzten lanak ez dira ugariak eta daudenek atal zehatz baino ez dute neurtzen (jolas librea, garapen psikomotorra...). Horrez gain, ikerketa gehienak Lehen Hezkuntzara mugatzen dira. Beraz, 4-5 urteko haurrekin burutuko den proiektu pilotu honen ebaluazio-sistema baten planteamenduak bi erronka nagusi azalarazi zituen. Alde batetik integrala izan behar zuela, hau da, ekimen honetan parte hartzen zuten haurren garapenean gerta zitezkeen balizko onuren ikuspegi global eta orokorra eman behar zuela. Eta bestalde, preseski Haur Hezkuntzako adinera zuzendua izan behar zuela.

Hori guztia kontuan hartuta, 1. taulan parte hartzen duten haurren ebaluazioa egiteko definitu diren hiru arloak eta 9 adierazleak jasotzen dira. Alde batetik, baso-eskolako ingurune fisiko eta natural bera ebaluatu nahi izan da hezkuntza-arlo modura. Bigarren arloan, haurren garapenean eragin zuzena zuten lau adierazle hautatu ziren: jolas librea eta inplikazioa, elkarreraginak eta estresa. Azkenik, eta baso-eskolako eredu pedagogikoa naturarekiko harreman zuzenean oinarritzen denez, ingurumenarekiko jarrerak eta jokabideak zein eduki kontzeptualak hobetzen diren ikusi nahi da.

1. taula

Ebaluazio-esparru eta adierazleei buruzko eskema orokorra

\begin{tabular}{|c|l|l|}
\hline $\begin{array}{c}\text { Ingurune fisiko } \\
\text { eta naturala }\end{array}$ & \multicolumn{1}{c|}{$\begin{array}{c}2 . \\
\text { Haurren garapen } \\
\text { pertsonaleko adierazleak }\end{array}$} & $\begin{array}{c}\text { Ingurune naturalarekin } \\
\text { harremana }\end{array}$ \\
\hline $\begin{array}{c}\text { 1.1 Ingurune fisiko eta ma- } \\
\text { teriala }\end{array}$ & 2.1 Jolas librea & 3.1 Jarrerak eta jokabideak \\
\hline $\begin{array}{c}\text { 1.2 Ingurune naturala } \\
\text { 1.3 Espazioekiko harre- } \\
\text { mana }\end{array}$ & 2.2 Inplikazioa & 3.2 Eduki eta prozesuak \\
\hline & 2.4 Estresa & \\
\hline
\end{tabular}

Adierazle gehienak hainbat ikerketatan oinarritu dira, baina baso-eskolako testuingurura eta Haur Hezkuntzako garapen mailara egokituz. Beste 
batzuk, ordea, gure ikerketa-taldeak ex-novo definitu ditu. Hurrengo atalean adierazleen deskribapen bat egingo da.

Ingurune naturalaren azterketa ataleko 1.1 eta 1.2 adierazleak ECERS (1998) eskalan jasotzen diren adierazleen moldaketa bat dira. Ikertzaileen behaketaren bitartez neurtzen dira, eta haurrak dauden ingurune fisikoko alderdi desberdinak neurtu dira, hala nola materialak (egituratuak, ez-egituratuak, naturalak...), segurtasun neurriak edo elementu naturalen eskuragarritasuna, besteak beste. Aipatu behar da ECERS eskalak baduela definituriko neurketa-metodologia bat, behaketan oinarritzen dena eta likert eskala batean kuantifikatu. Beraz, kasu honetan horren moldaera egin da, ingurune natural batean erabili ahal izateko.

1.3. indikatzailea, aldiz, haur-taldeari egindako elkarrizketa baten bidez kuantifikatzen da, haurrek espazio fisiko eta naturalekin sortzen dituzten harremanak aztertzen direlako honen bidez. Kaplan eta Kaplanek (1989) Lehen Hezkuntzarako garatutako eskala baten moldaketa da, ART teorian (Attention Restoration Theory) oinarritzen dena. Haurren eta ingurune naturalaren arteko harremanean oinarritutako lau arloren inguruan galdetzen zaie: lilura, bateragarritasuna, harreman fisikoa eta abstrakzio psikologikoa (being away psicologically, fascination, extent and compatibility).

Bigarren ebaluazio-arloan oso bestelakoak diren lau adierazle ezberdin aztertu dira, baina haurren garapen emozional eta afektiboa modu orokor batean ezagutzeko baliagarriak izan daitezkeenak. Baso-eskolako eredu pedagogikoan jolas libreari eskainitako garrantzia dela-eta, jolasa nolakoa den eta nola gertatzen den aztertu nahi da (2.1 adierazlea), baita honen inplikazio-maila ere (2.2 adierazlea). Adierazle horiek oinarrituta daude maiz erabiliak izan diren Jolaserako Behaketa Eskalan (Play Observation Scale, Rubin, 1989) eta Haurren Ikasketa Goiztiar Eraginkorrerako Programako Inplikazio Eskalan (Effective Early Learning Programme Child Involvement Scale, Laevers, 1995), nahiz eta testuingurua lan honetarako egokitu den. Horrez gain, haurren arteko eta helduekiko harremanak (2.3 adierazlea, ECERS eskalatik eratorria) eta estres maila (2.4 adierazlea) aztertu dira. Azken hau Carrusek (2012) egindako ikerketan oinarrituta. Lau adierazle hauek haurren behaketaren bidez neurtzen dira.

Azkenik, baso-eskolak inguruneko ezagutzari dagokionez onura zuzen batzuk izango dituela-eta, hirugarren arloan jarrerak eta jokabideak neurtu nahi izan dira alde batetik (3.1 adierazlea), eta ezagutzak bestetik (3.2 adierazlea). Lehen kasuan, haurren lagin-talde batean egindako elkarrizketen bidez neurtuko da, Manoli, Johnson eta Dunlapek (2007) garatutako metodologietan oinarrituz jarrerei dagokienez eta Kahriman-Ozturk, Olgan eta Tuncerrek (2012) garatutako metodologietan jokabideen kasuan. Bukatzeko, 3.2 adierazlea tutoreei egindako aldikako galdeketen bidez aztertuko da, haurren natur ingurunearekiko ezagutza kontzeptualak (bizidun ereduaren garapenari, landareen zaintzari, eredu meteorologikoak...) eta 
erabilitako prozeduren (behaketak, esperimentazioak...) inguruan (Chalufour eta Worth, 2003).

Neurketa hauek ikasturtearen hasieran, amaieran eta momentu ezberdin batzuetan egingo dira. Aldiz, eskola kontrasteen neurketak urtearen hasiera eta amaieran izango dira. Edonola ere, egunero basoan sortzen diren momentu kritiko eta esanguratsuak jasoko dituzte hezitzaile eta tutoreek, batez ere bideo grabaketak eginez. Bideo hauek, kodifikatu eta aldiro aztertuko dira ikertzaileekin batera, baso eskolako proiektuaren hainbeste alderdien eboluzio jarrai bat lortuz.

Tutoreen ebaluazioaren kasuan, ebaluazio partehartzaile baten garapenean zentratu behar izan dugu, segurtasuna, beharrizanak, aspirazioak eta baso-eskolako lorpenei buruzko pertzepzio desberdinak adierazteko aukera ematen duten talde-saio ugariekin. O'Brienek (2009) sortutako metodologia hau, elkarlanean egindako poster saio batekin hasten da eta bertan itemak definitzen dira (aipatutako pertzepzio horiek), proiektuan zehar aldizka analizatuz doazenak.

\section{ONDORIOAK}

Lan honetan UPV/EHUren eta Kutxa Ekogunearen artean garatu den baso-eskola proiektu pilotuko ebaluaziorako adierazleen definizio prozesua jaso da. Proiektu hau berritzailea da eskolek 2017-2018 urtean zehar ohiko pedagogia eta baso-eskola uztartu dituztelako. Haurrek esperientzia jarraia izan dute ingurune naturalarekin eta honek onura potentzial ugari izan ditzake arlo kognitibo, kontzeptual, afektibo edo emozionalean. Esperientzia oparo hori ebaluazio-eredu bat sortzeko aukera ezin hobea zela iruditzen zitzaigun.

Lehen aipatu dugun moduan, hiru arlo ezberdin aztertu dira bederatzi adierazleren bitartez. Alde batetik, baso-eskolako espazioen egokitasuna eta erabilgarritasuna neurtu da testuinguru pedagogiko bezala; bestalde, haurren hezkuntza eta giza-garapenean eragina izan dezaketen faktore batzuk aztertu dira, hala nola jolas librea edo haurren arteko harremanak. Hirugarren arloan, eta baso-eskola naturako elementuen behaketa eta esperimentazioa bultzatzen den eredu pedagogikoa izanda, haurrek ingurune naturalarekiko garatu ditzaketen jarrera eta eduki kontzeptualen lorpen maila ezagutu nahi izan da.

Adierazle hauetariko batzuk lan honetarako propio garatu dira, baina beste batzuk beste ikerketetan oinarritutako moldaerak dira. Kasu honetan Haur Hezkuntzako etapara egokitu dira, orain arteko ikerketa gehienak 6 urtetik aurrerako haurrak ebaluatzeko garatu zirelako.

Adierazle gehienak behaketa zuzenaren eta tutoreen pertzepzioaren bidez neurtu dira. Bederatzi adierazleetatik soilik bi dira haurrekin elkarrizketa bidez landu direnak. 
Nahiz eta ebaluazio-eredu hau Kutxa Ekoguneko baso-eskola proiekturako garatu den, antzeko eredua ezartzeko bidean dagoen edozein eskolak erabili ahal izango du etorkizunean. Azken finean, lan honek haurraren eta naturaren arteko kontaktuak dakartzan onurak aztertzen dituzten ikerketei ekarpena egin nahi izan die, eta bide batez baso-eskola bezalako hezkuntza-eredu berritzaile hau legitimatu eta bultzatu nahi izan du.

\section{ERREFERENTZIAK}

Ausubel, D., Novak, J., \& Hanesian, H. (1978). Educational Psychology: A Cognitive View (2nd Ed.). New York: Holt, Rinehart \& Winston.

Carrus, G., Pirchio, S., Passiatore, Y., Mastandrea, S., Scopelliti, M., \& Bartoli, G. (2012). Contact with Nature and Children's Wellbeing in Educational Settings. Journal of Social Sciences, 8 (3), 304-309.

Clark, A. (2007). Views from inside the shed: young children's perspectives of the outdoor environment, Education 3-13, 35(4), 349-363.

Chalufour, I. \& Worth, K. (2003). Discovering nature with young children. St. Paul, MN: Redleaf Press.

Dattner, R. (1969). Design for Play. New York: Van Nostrand Reinhold Co.

Driver, R. (1983). The pupil as scientist? Milton Keynes, England: Open University Press.

ECERS-R, Early Childhood Environmental Rating Scale-Revised version (1998). New York: Teacher College Press.

Ernst, J. (2014). Early childhood educators' use of natural outdoor settings as learning environments: an exploratory study of beliefs, practices, and barriers. Environmental Education Research, 20, 735-752.

Essa, E. (1981). An outdoor play area designed for learning. Day Care and Early Education, 9, 37-42.

Eusko Jaurlaritza, 237/2015 Dekretua, abenduaren 22koa, Haur Hezkuntzako curriculuma zehaztu eta Euskal Autonomia Erkidegoan ezartzekoa.

Falk, J., \& Dierking L. (2002). Lessons without limit: How free choice learning is transforming education. New York: Altamira Press.

Fjørtoft, I. (2004). The natural environment as a playground for children:the impact of outdoor play activities in pre-primary school children. Early Childhood Education Journal, 29 (2), 111-117.

Frabboni, F. (1980). El Primer Abecedario: El Ambiente. Barcelona: Ed. Fontanella.

Garcia Ruiz, M.J. (2013). Enseñar y aprender en educación infantil a través de proyectos. Santander: Publicam, Universidad de Cantabria.

Gardner, H. (1983). Frames of mind. The theory of multiple intelligences. New York: Basic Books.

Gardner, H. (1999). Intelligence Reframed: Multiple Intelligences for the 21 st Century. New York: Basic Books.

Ghafouri, F. (2014). Close encounters with nature in an urban kindergarten: a study of learners' inquiry and experience. Education 3-13, 42, 54-76. 
Baso-eskola proiektu pilotuko haurren ebaluazio hezigarria burutzeko...

Guldberg, H. (2009). Reclaiming childhood. Freedom and play in an age of fear. Abingdon: Routledge.

Harris, F. (2015). The nature of learning at forest school: practitioners' perspectives, Education 3-13, 101-112.

Jackson, Y. (2001). Reversing underachievement in urban students: Pedagogy of confidence. A. Costa (Ed.), Developing minds. Volume III (pp. 222-228). Alexandria, VA: Association for Supervision and Curriculum Development.

Kahriman-Ozturk, D., Olgan, R., \& Tuncer, G. (2012) A qualitative study on turkish preschool children's environmental attitudes through ecocentrism and anthropocentrism. International Journal of Science Education, 34 (4), 629-650.

Kamii, C., \& De Vries, R. (1989). El conocimiento físico en la educación preescolar. Implicaciones de la teoría de Piaget. Madrid: Editorial Siglo XXI.

Kaplan, R., \& Kaplan, S. (1989). The experience of Nature. Nueva York: Cambridge University Press.

Kuh, L.P., (2014). Thinking critically about environments for young children: Bridging theory and practice. New York: Teachers College Press.

Laevers, L. (1995). Well-being and involvement in care settings. A process-oriented self-evaluation instrument. Leuven, Belgica: Research Centre for Experiential Education.

MacKinder, M. (2015). Footprints in the woods: 'tracking' a nursery child through a Forest School session. Education 3-13, 2-12.

Magraw, L. (2011). Outdoor provision in the early years. Chapter 2: Following children's interest: Children led experiences that are meaningful and worthwhile. J. White (Ed.), London, England: SAGE Publications Ltd.

Manoli, C., Johnson, B., \& Dunlap, R. E. (2007). Assessing children's environmental worldviews: Modifying and validating the New Ecological Paradigm Scale for use with children. Journal of Environmental Education, 38, 3-13.

Martin, J.M., Raynice, J.-S., \& Schmidt, E. (2005). Process oriented inquiry a constructivist approach to Early Childhood Science Education: Teaching teachers to do Science. Journal of Elementary Science Education, 17 (2), 13-26.

Maynard, T. (2007). Learning in the outdoor environment: A missed opportunity? Early Years, 27, 255-265.

McClintic, S. (2015). Exploring early childhood teachers' beliefs and practices about preschool outdoor play: A qualitative study. Journal of Early Childhood Teacher Education, 36, 24-43.

Montessori, M. (1909/2016). El método de la pedagogía científica: Aplicado a la educación de la infancia. Madrid: Biblioteca Nueva. Jatorrizko idazketa data: 1909.

O'Brien, L. (2009). Learning outdoors: the Forest School approach. Education 3-13, 37(1), 45-60.

O’Neill, K.D. \& Polman, J.L. (2004). Why Educate «Little Scientists?» Examining the potential of practice-based scientific literacy. Journal of Research in Science Teaching, 41, 234-266.

Pedreira, M. (2006). Dialogar con la realidad. Cuadernos Praxis para el profesorado. Educación Infantil. Orientaciones y Recursos. Barcelona: CISS_Praxis.

Pestalozzi, J.H. (1816-1819, 2006). Cartas sobre educación infantil. Madrid: Tecnos. Jatorrizko idazketa data: 1816-1819. 
Piaget, J. (1964/2003). Development and learning. Journal of Research in Science Teaching, 40(1), 8-18. (Original work published in 1964).

Pikler, E. (1969). Moverse en libertad. Desarrollo de la motricidad global. Madrid: Ed. Narcea.

Ridgers, N.D., Knowles, Z., \& Sayers, J. (2012). Encouraging play in the natural environment: a child-focused case study of Forest School. Children's Geographies, 10(1), 49-65.

Rubin, K.H. (1989). The Play Observation Scale. Ontario, Canada: University of Waterloo.

Siry, C. (2014). Towards multidimensional approaches to early childhood science education. Cultural Studies of Science Education, 9, 297-304.

Thomas, F. \& Harding, S. (2011). The role of play: Play outdoors as the medium and mechanism for well-being, learning and development. In J. White (Ed.), Outdoor provision in the early years (pp. 12-22). London, England: SAGE Publications Ltd..

Vigotsky, L.S. (1979). El desarrollo de los procesos psicológicos superiores. Barcelona: Gribaljo.

Waite, S. (2015). Comparing apples and pears?: a conceptual framework for understanding forms of outdoor learning through comparison of English Forest Schools and Danish udeskole. Environmental Education Research, 22(6), 868-892.

Waller, T., Sandseter E., Wyver S., Ärlemalm-Hagsér, E., \& Maynard, T. (2010). The dynamics of early childhood spaces: opportunities for outdoor play? European Early Childhood Education Research Journal, 18:4, 437-443.

Wilson, R. (2008). Nature and young children: Encouraging creative play and learning in natural environments. New York, NY: Routledge. 